\title{
Use of giant reed (Arundo donax L.) to control soil erosion and improve soil quality in a marginal degraded area
}

\author{
Donato Visconti, ${ }^{1}$ Nunzio Fiorentino, ${ }^{1}$ Eugenio Cozzolino, ${ }^{2}$ Ida di Mola, ${ }^{1}$ Lucia Ottaiano, ${ }^{1}$ \\ Mauro Mori, ${ }^{1}$ Vincenzo Cenvinzo, ${ }^{1}$ Massimo Fagnano ${ }^{1}$ \\ ${ }^{1}$ Department of Agricultural Sciences, University of Naples Federico II, Portici (NA); ${ }^{2}$ Council for \\ Agricultural Research and Economics (CREA), Research Center for Cereal and Industrial Crops, Caserta, \\ Italy
}

\begin{abstract}
Soil erosion is one of the biggest environmental problems throughout European Union causing considerable soil losses. Vegetation cover provides an important soil protection against runoff and soil erosion. To this aim, unlike annual crops, perennial plants have the advantage of covering soil for a longer time and reducing soil erodibility thanks to SOM increase due to litter effect and to reduction of soil disturbance (no-tillage). Two experiments were carried out in marginal hilly areas (10\% slope) of Southern Italy: i) long-term experiment in which it was evaluated the effect of two fertilization doses (N: 100 and $50 \mathrm{~kg} \mathrm{~N} \mathrm{ha}^{-1}$ from urea) on Arundo donax L. biomass production as well as its effect on soil erosion; ii) three-year experiment to evaluate the soil cover capacity of the giant reed by analysing the plant leaf area index (LAI). Results of the two experiments showed a good soil protection of Arundo donax L. that reduced soil losses by $78 \%$ as compared to fallow and showed soil erosion reduction not different from permanent meadow thanks to the soil covering during the period with the highest rain erosivity and to the reduction in soil erodibility. The protective effect of Arundo donax L. from rain
\end{abstract}

Correspondence: Donato Visconti, Nunzio Fiorentino, Department of Agricultural Sciences, University of Naples Federico II, via Università 100, 80055 Portici (NA), Italy.

Tel.: +39.081.2539126/2539129.

E-mail: donato.visconti@unina.it ; nunzio.fiorentino@unina.it

Key words: Runoff; Arundo donax; perennial crops; soil fertility; leaf area index.

Acknowledgements: this study was financed by the Life Ecoremed Project (LIFE11/ENV/IT/275). We would like to thank Roberto Maiello and Sabrina Nocerino for their support in laboratory work. We would also thank Vincenzo Leone for his support in crop management and sampling.

Received for publication: 29 October 2020.

Accepted for publication: 29 October 2020.

${ }^{\circ}$ Copyright: the Author(s), 2020

Licensee PAGEPress, Italy

Italian Journal of Agronomy 2020; 15:1764

doi:10.4081/ija.2020.1764

This article is distributed under the terms of the Creative Commons Attribution Noncommercial License (by-nc 4.0) which permits any noncommercial use, distribution, and reproduction in any medium, provided the original author(s) and source are credited. erosivity was also confirmed by LAI analysis that showed a good soil covering of giant reed in the above mentioned period, even during the initial yield increasing phase following crop transplant. According to biomass yield, from the fifteen year of cultivation in a low fertile inland hilly area of Southern Italy, giant reed was characterized by a yield-decreasing phase that resulted postponed as compared to more fertile environments thus ensuring a longstanding soil protection from soil erosion. In addition, the higher nitrogen fertilization dose (100 kg ha ${ }^{-1}$ of $\left.\mathrm{N}\right)$ allowed interesting biomass yield as compared to the lower dose $\left(50 \mathrm{~kg} \mathrm{~N} \mathrm{ha}^{-1}\right)$ and kept constant SOC along the year of experimentation due to an improved contribution of leaf fall, root exudates and root turnover to soil.

\section{Introduction}

Soil erosion is one of the main environmental threats through the European Union (Guerra et al., 2016). The main causes of soil erosion comprise human activities such as incorrect soil cultivation, overgrazing and deforestation combined with natural events such as steep topography and heavy rainfall (Ricci et al., 2020). The main consequences of soil erosion are the pollution of water, reduction in water storage capacity of soil and loss of nutrients and organic matter causing the reduction of crop yield (Cerdan et al., 2010; Rickson, 2014; Wang et al., 2020). Soil erosion by water is divided into two main processes: the detachment of soil particles from the soil and their subsequent transport (Webster, 2005). It was suggested that a soil loss of more than $1 \mathrm{Mg} \mathrm{ha}^{-1} \mathrm{yr}^{-1}$ might be considered as irreversible over a period of 50-100 years due to the very low soil formation rate (Durán and Rodriguez, 2008). The Mediterranean region is particularly vulnerable to soil erosion due to the existence of rills, gullies and eroded torrential headwaters that contributed to high sediment yield (Vanmaercke et al., 2011). In addition, susceptibility to soil erosion of Mediterranean region is enhanced by the intensive cultivation on steep slopes and by the alternance of long dry periods with intense rainfall events (Durán and Rodriguez, 2008; García-Ruiz et al., 2013). It was estimated that about $44 \%$ of the Mediterranean area is vulnerable to soil erosion by water (Pena et al., 2020).

Vegetation cover provides an important soil protection against runoff and soil erosion by reducing erosivity of rain and water erosion rate because of the protective effect of soil by plant canopy and leaf litter (Montagnoli et al., 2016). In this respect, many authors indicated that the leaf area index (LAI) is correlated to the reduction of rainfall kinetic energy and sediment concentration by vegetation canopy (Zhang et al., 2003; Klima and WiśniowskaKielian, 2006; Song et al., 2018). In addition, the protection from 
soil erosion is supported by the improvement of soil physicochemical features (Jien and Wang, 2013) and by the effect of plants roots on soil aggregation and soil erodibility (Ola et al., 2015).

Soil erosion is particularly intense in some environments like sloping farmlands due to the lack of a long-term stable vegetation cover that report seasonal variations according to crop cycle (Ma et al., 2016). Furthermore, during the stages of tillage, sowing, and seedling, the soil is not covered by vegetation thus favouring soil erosion (Ma et al., 2016). Unlike annual crops, perennial plants have the advantage of covering soil for a longer time, reducing soil disturbance and providing a constant input of organic matter thanks to the litter effect (Fernando et al., 2010; Durán et al., 2013). Among the different perennial crops, giant reed (Arundo donax L.) has received a great interest in recent years due to its tolerance to many environmental stresses (contamination, pests, salts; Di Mola et al., 2018) and its beneficial effect on soil organic carbon, soil structure and water retention (Pulighe et al., 2019). In addition, giant reed is characterized by fast grown rate and high yield (Fierro et al., 2019) and provides a lignocellulosic biomass viable for bioenergy, biofuels, chemicals, biopolymers, biocomposites and construction materials (Calvo et al., 2018). Fagnano et al. (2015) also suggested that giant reed might mitigate soil erosion by reducing water runoff and, indirectly, soil erodibility.

Farmers because of low income and high water erosion gradually abandon many hilly farmlands in Campania region (southern Italy) cultivated with cereals (Forte et al., 2018). In this respect, the cultivation of perennial lignocellulosic non-food crops such as giant reed may be beneficial for farmers by reducing soil erosion and agronomic input requirements. Therefore, the aims of this study were to evaluate: i) the giant reed effect on soil erosion and soil quality by comparing two fertilization doses in a five years field trial; ii) the soil cover capacity of the giant reed under low agronomic inputs conditions (without irrigation and fertilization) in a three years field trial.

\section{Materials and methods}

Two experiments were carried out in marginal slope areas (10\% slope) of southern Italy (Sant'Angelo dei Lombardi $40^{\circ} 92^{\prime} \mathrm{N}, 15^{\circ} 12^{\prime} \mathrm{E}, 700 \mathrm{~m}$ a.s.1.).

The study area climate was typical of Mediterranean area, with hot and dry summer and cold winter with many days (up to 62 days per year) showing daily absolute minimum (min) temperatures below zero. The minimum temperatures ranged between -7 and $-4{ }^{\circ} \mathrm{C}$ while the maximum $(\max )$ temperatures were between 33 and $39^{\circ} \mathrm{C}$ along the years of experimentation (Table 1).

Water balance (WB) was calculated as the difference between cumulative rainfalls and reference Evapotranspiration $\left(\mathrm{ET}_{0}\right.$;
Hargreaves et al., 1985) for each year. Reference evapotranspiration was calculated as following:

$E T_{0}=0.0023 R_{a}\left(T_{\text {mean }}+17.8\right)\left(T_{\max }-T_{\text {min }}\right)^{0.5}$

where: $R_{a}$ is the extra-terrestrial solar radiation $\left(\mathrm{mm} \mathrm{day}^{-1}\right) ; T_{\max }$ is the mean daily maximum temperature $\left({ }^{\circ} \mathrm{C}\right) ; T_{\min }$ is the mean daily minimum temperature $\left({ }^{\circ} \mathrm{C}\right) ; T_{\text {mean }}=\left(T_{\max }-T_{\min }\right) / 2$.

Water balance showed high water surplus in autumn-winter (from November to March) every year of experimentation ranging from $217 \mathrm{~mm}$ in 2017 to $506 \mathrm{~mm}$ in 2016 (Table 1). During this period the soil of the farmland is covered only by traditional crops of the area (i.e., durum wheat) that have limited soil protection by soil erosion. The driest months that reported the highest mean temperatures and water deficit (Figure 1) were July $\left(35^{\circ} \mathrm{C} ;-126 \mathrm{~mm}\right)$ and August $\left(35^{\circ} \mathrm{C} ;-119 \mathrm{~mm}\right)$.

A 15-years long-term experiment was carried out in which two fertilization doses ( $\mathrm{N}$ : 100 and $50 \mathrm{~kg} \mathrm{~N}^{-1}$ from urea applied in March of each year) were compared and arranged on a randomized complete block design with three replicates. The soil of the study area was characterized by clay loam texture, low organic matter (OM) content and alkaline $\mathrm{pH}$ (Table 2) (Mori and Di Mola, 2012).

Giant reed rhizomes were transplanted in February 2004 at the density of 1 plant $\mathrm{m}^{-2}$ in $140 \mathrm{~m}^{2}$ (10 m wide $\times 14 \mathrm{~m}$ length) plots with a $10 \%$ constant slope. Three fallow plots and one plot covered by permanent meadow were included as negative and positive control, respectively, to assess the vegetation effect on soil water erosion. Runoff from each plot was collected by conveying the runoff to tanks by a logline at the lower end of each plot. Runoff was eval-

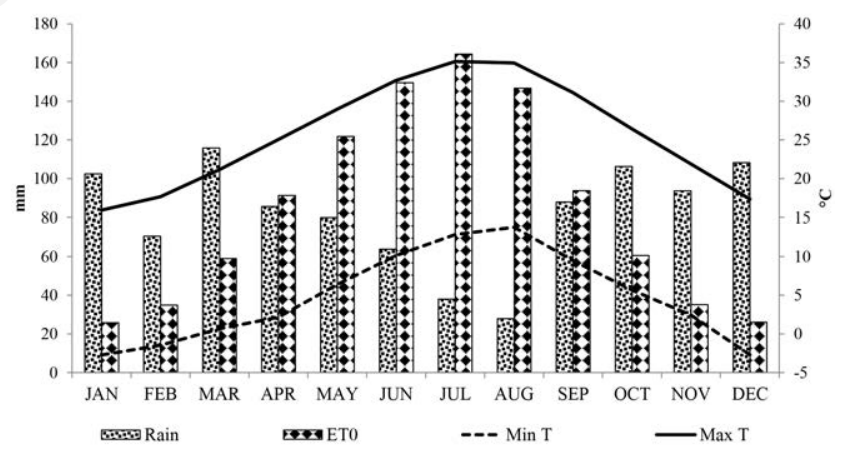

Figure 1. Monthly rainfall, temperatures and ET0 of the study area - Average values (2014-2018). $\mathbf{E T}_{0}$, Evapotranspiration; Max T, Maximum temperature; Min T, Minimum temperature.

Table 1. Temperatures (average values) and water balance (2014-2018) of the study area.

\begin{tabular}{|c|c|c|c|c|c|c|c|c|}
\hline \multirow[t]{2}{*}{ Year } & \multicolumn{3}{|c|}{ Temperature $\left({ }^{\circ} \mathrm{C}\right)$} & \multicolumn{3}{|c|}{ Water balance (mm) } & \multirow[b]{2}{*}{$\begin{array}{c}\text { Rain } \\
\left(\mathrm{mm} \mathrm{yr}^{-1}\right)\end{array}$} & \multirow[b]{2}{*}{$\begin{array}{c}\mathrm{ET}_{0} \\
\left(\mathrm{~mm} \mathrm{yr}^{-1}\right)\end{array}$} \\
\hline & Average & Absolute max & Absolute min & Apr-Oct & Nov-Mar & Year & & \\
\hline 2014 & 13 & 33 & -7 & -307 & 273 & -33 & 1012 & 1046 \\
\hline 2015 & 17 & 37 & -4 & -482 & 218 & -264 & 844 & 1108 \\
\hline 2016 & 15 & 34 & -5 & -292 & 506 & 214 & 1274 & 1061 \\
\hline 2017 & 16 & 39 & -6 & -515 & 217 & -297 & 642 & 940 \\
\hline 2018 & 15 & 35 & -4 & -97 & 332 & 235 & 1125 & 890 \\
\hline
\end{tabular}


uated by measuring the water level in the tanks after each effective rainfall, then the suspension (runoff and sediments) were mixed thoroughly and samples of approximately $1 \mathrm{~L}$ were taken and oven dried at $105^{\circ} \mathrm{C}$ to determine the sediment concentration $\left(\mathrm{g} \mathrm{L}^{-1}\right)$ (Fagnano et al., 2015). Each plot was enclosed by $40 \mathrm{~cm}$ metal sheets fixed into the soil, for ensuring that collected water only derives from runoff from the same plot. The amount of eroded soil $\left(\mathrm{kg} \mathrm{ha}^{-1}\right)$ was calculated from runoff volume $\left(\mathrm{m}^{3} \mathrm{ha}^{-1}\right)$ and sediment concentration $\left(\mathrm{g} \mathrm{L}^{-1}\right)$. Giant reed biomass yield and soil erosion from 2004 to 2012 were reported by Fagnano et al. (2015) while results of the last five years are showed in this study (from 2014 to 2018). Plant shoots were harvested in the winter after each growing cycle (February) on $10 \mathrm{~m}^{2}$ sampling areas and the total biomass was weighted (fresh weight). Then, a subsample (1 kg) of each fraction was oven dried at $70^{\circ} \mathrm{C}$ to constant dry weight. A bulk soil sample (0-20 cm layer) was collected from each replicate at the beginning (T0 - 2014) and at the end of the experimentation (T1 - 2018). Soil sample was dried at $70^{\circ} \mathrm{C}$ until constant weight, homogenized and sieved at $2 \mathrm{~mm}$ before analysis of organic carbon (SOC) content (Walkley and Black, 1934).

A three-year experiment was carried out on a $200 \mathrm{~m}^{2}$ area to evaluate the soil cover capacity of giant reed cultivated in low input cropping system (without irrigation and fertilization). The soil of the study area was characterized by clay texture, OM content and sub-alkaline pH (Table 3) (Mori and Di Mola, 2012).

Rhizomes (local ecotype) were transplanted on spring 2014 at a density of 2.1 plant $\mathrm{m}^{-2}(0.6 \times 0.8 \mathrm{~m})$. Aboveground biomass (culms+leaves) was collected on $2 \mathrm{~m}^{2}$ sampling area at monthly intervals from July 2014 (4 plants per sampling) until to December 2016. Leaves were separated from culms and leaf area $\left(\mathrm{m}^{2}\right.$ plant $\left.{ }^{-1}\right)$ was measured for each plant by using LI-3100C Area Meter (LICOR, Lincoln, NB, USA). LAI $\left(\mathrm{m}^{2} \mathrm{~m}^{-2}\right)$ was calculated by multiplying the leaf area by the plant density.

\section{Statistical analysis}

The statistical analyses were all carried out by using Ms Excel 2013 and SPSS 21 (SPSS Inc. Chicago, USA). All data were subjected to analysis of variance (ANOVA) using a general linear model and means were separated according to LSD test with $\mathrm{P}<0.05$. Normality of distribution and homogeneity of variance were verified by using the Kolmogorov-Smirnov and Levene tests, respectively. Logarithmic transformation was applied to studied variables to ensure normality of distribution. The LAI data was subjected to regression analysis (Impagliazzo et al., 2017).

\section{Results and discussion}

\section{Long-term giant reed biomass yield}

During the first 4 years of the monitoring period, the giant reed biomass yield showed an oscillatory pattern with significantly lower values in 2015 and 2017 (Table 4) probably due to the higher water deficit reported in these two years in the period (Apr-Oct) when giant reed growth is higher in the studied area (Table 1; Impagliazzo et al., 2017). In addition, a decreasing trend (-24.0\%) was recorded with yields lowering from 2017 to 2018 (Table 4). Angelini et al. (2009) reported a similar yield reduction from the ninth year of experimentation in a twelve years field trial reporting an average yield of $25.5 \mathrm{Mg} \mathrm{ha}^{-1}$ (from $9^{\text {th }}$ to $12^{\text {th }}$ ) that was higher than that of our field trial $\left(14.9 \mathrm{Mg} \mathrm{ha}^{-1}\right)$. This difference was probably due to lower temperatures and lower fertility of our site (low content of organic matter in the studied soil). Oppositely, giant reed yields in our field trial were in accordance to those from Nassi o Di Nasso et al. (2010) who described a ten-year experiment relative to giant reed cultivation on low fertility soils. Therefore, according to our findings, we can hypothesize that even if giant reed biomass yield was lower as compared to more fertile environments (characterized by high soil organic matter content), a longer lag phase with constant production and consequently a longer time soil protection was reached.

Plant height showed no significant differences along the years of experimentation (Table 4) presenting a lower height $(188 \mathrm{~cm}$ on the average) than height value ( $216 \mathrm{~cm}$ on the average) reported by Fagnano et al. (2015) in previous years (2004-2012) of the same field trial. Dry matter (\%) of biomass was $50 \%$ on the average and varied during the different years (Table 4) probably due to weather seasonal variations in accordance with Angelini et al. (2005). Dry matter content of giant reed biomass is an important parameter for biomass storage and use as raw material for energy (woodchip) or biogas and biofuel production (Dragoni et al., 2015; Corno et al., 2016). Fagnano et al. (2015) and Bonfante et al. (2017) tested giant reed in marginal areas of Southern Italy reporting an average biomass yield close to that of our study $\left(15 \mathrm{Mg} \mathrm{ha}^{-1}\right)$ and concluding that giant reed cultivation may be a valid alternative to traditional crops of marginal non-irrigated areas (i.e. durum wheat) by increasing farm incomes with woodchip biomass production.

The higher $\mathrm{N}$ fertilization level (N100) increased biomass production by $18.0 \%$ and culm height by $2.1 \%$ on the average as compared to N50 (Table 4) and this result is in accordance with previ-

Table 2. Initial soil physicochemical properties before the long-term experiment.

\begin{tabular}{cccccccc} 
Layer $(\mathrm{cm})$ & Sand $(\%)$ & Silt $(\%)$ & Clay $(\%)$ & $\mathrm{pH}$ & TN $\left(\mathrm{g} \mathrm{kg}^{-1}\right)$ & OM $\left(\mathrm{g} \mathrm{kg}^{-1}\right)$ & OC $\left(\mathrm{g} \mathrm{kg}^{-1}\right)$ \\
\hline $0-20$ & 36.9 & 24.3 & 38.8 & 8.07 & 1.01 & 15.1 & 9.1 \\
\hline
\end{tabular}

Table 3. Initial soil physicochemical properties before the three-year experiment.

\begin{tabular}{|c|c|c|c|c|c|c|c|}
\hline Layer $(\mathrm{cm})$ & Sand (\%) & Silt (\%) & Clay (\%) & $\mathrm{pH}$ & TN $\left(\mathrm{g} \mathrm{kg}^{-1}\right)$ & OM $\left(\mathrm{g} \mathrm{kg}^{-1}\right)$ & OC $\left(\mathrm{g} \mathrm{kg}^{-1}\right)$ \\
\hline $0-20$ & 37.0 & 19.9 & 43.1 & 7.80 & 0.10 & 13.0 & 7.8 \\
\hline
\end{tabular}


ous works (Fagnano et al., 2015; Impagliazzo et al., 2017) suggesting that $\mathrm{N}$ inputs are mandatory to allow high biomass yields in the studied site. The higher $\mathrm{N}$ dose may also increase the aboveground biomass combustion by reducing ashes accumulation in the aboveground biomass due to high nutrient availability to plants and their consequent translocation to rhizomes (Nassi o Di Nasso et al., 2009).

\section{Giant reed soil cover potential}

LAI was described by a quadratic function for all the three years showing a linear increase during the first year until October (DOY: $304 ; 1.8 \mathrm{~m}^{2} \mathrm{~m}^{-2}$ on the average) while there was a LAI decrease during the next two months due to winter cold (Figure 2). Differently, during the next two years, because of colder weather conditions, the LAI peak was reached in August reporting a LAI value of $2.9 \mathrm{~m}^{2} \mathrm{~m}^{-2}$ in the second year and of $4.2 \mathrm{~m}^{2} \mathrm{~m}^{-2}$ in the third year.

In our experiment LAI average value showed an increasing trend during the three years of experimentation as also observed by Impagliazzo et al. (2017) in a ten-year giant reed growth analysis carried out in the same area. It is a likely hypothesis that LAI values from the last year of our experimentation are representative of plant cover during the successive cropping cycles, suggesting a potential long-lasting effect of giant reed on soil coverage. This because our results belong to the 4-year yield increasing phase of giant reed, that leads to a plateau value kept almost for the following 10 years in Mediterranean environments as also observed by Angelini et al. (2009) and Bonfante et al. (2017).

Furthermore, by comparing the LAI average values of the last two year of experimentation with corresponding water balance values (Figure 3), high LAI values were recorded during the months characterized by the highest water surpluses $\left(1.7,1.4\right.$ and $0.8 \mathrm{~m}^{2}$ $\mathrm{m}^{-2}$ for October, November and December, respectively). Some authors showed a negative correlation between LAI and soil loss (Zhang et al., 2011) suggesting that crops allowing high soil coverage can significantly reduce soil erosion. Klima et al. (2016) showed that a winter crop of the same family of giant reed (Poaceae) may reduce soil loss intensity efficiently when LAI was higher than $0.4 \mathrm{~m}^{2} \mathrm{~m}^{-2}$ and showing max soil loss reduction when LAI was higher than $1.6 \mathrm{~m}^{2} \mathrm{~m}^{-2}$ thus suggesting a good soil protection by giant reed during the months (i.e., SeptemberNovember) characterized by higher rain erosivity in Mediterranean

Table 4. Biomass yield (Mg ha $\left.{ }^{-1} \mathrm{DW}\right)$, dry matter content (\%) and culm height $(\mathrm{cm})$ of giant reed along the five years of experimentation. N50 and N100 are the two fertilization doses (50 and $100 \mathrm{~kg} \mathrm{~N} \mathrm{ha}^{-1}$ ).

\begin{tabular}{|c|c|c|c|c|}
\hline & & $\begin{array}{l}\text { Biomass yield } \\
\left(\mathrm{Mg} \mathrm{ha}^{-1} \text { d.w. }\right)\end{array}$ & $\begin{array}{l}\text { Dry matter } \\
(\%)\end{array}$ & $\begin{array}{l}\text { Height } \\
\text { (cm) }\end{array}$ \\
\hline Year & $\begin{array}{l}2014 \\
2015 \\
2016 \\
2017 \\
2018\end{array}$ & $\begin{array}{l}18.8^{\mathrm{a}} \\
12.4^{\mathrm{b}} \\
17.5^{\mathrm{a}} \\
14.0^{\mathrm{b}} \\
11.8^{\mathrm{b}}\end{array}$ & $\begin{array}{l}49^{b} \\
50^{b} \\
56^{a} \\
50^{b} \\
49^{b}\end{array}$ & $\begin{array}{l}184 \\
179 \\
200 \\
192 \\
184\end{array}$ \\
\hline Fertilization & $\begin{array}{l}\text { N50 } \\
\text { N100 }\end{array}$ & $\begin{array}{l}13.5 \\
16.4\end{array}$ & $\begin{array}{l}51 \\
49\end{array}$ & $\begin{array}{l}186 \\
190\end{array}$ \\
\hline Significance & $\begin{array}{l}\text { Year } \\
\text { Fertilization } \\
Y \times F\end{array}$ & $\begin{array}{l}* * \\
* * \\
\text { n.s. }\end{array}$ & $\begin{array}{l}* * \\
\text { n.s. } \\
\text { n.s. }\end{array}$ & $\begin{array}{l}\text { n.s. } \\
\text { n.s. } \\
\text { n.s }\end{array}$ \\
\hline
\end{tabular}

a,bValues followed by the same letter do not differ significantly according to the LSD test $(\mathrm{P}<0.05)$. ${ }^{* *} \mathrm{P}<0.01 ;$ n.s., not significant. environment (Diodato et al., 2009, 2011). In addition, in January, February and March when water surplus are still high (Figure 3), Cosentino et al. (2015) suggested that the continuous release of organic residues by giant reed ensure a mulching effect that may reduce the effect of heavy rains contributing to soil erosion reduction.

\section{Long-term effect of giant reed on soil organic C}

At the end of the monitoring period (T1) the SOC content of N100 treatment was $13 \%$ higher than N50 and no SOC variation was recorded for the highest $\mathrm{N}$ dose compared to the initial values (T0). This result was probably due to the higher biomass production of N100 that likely increased crop residues to soil (litterfall) and also enhanced root exudates and root turnover to soil as suggested by Fagnano et al. (2015). Furthermore, Fernando (2013) indicated that soil $\mathrm{C}$ was also better protected by the litter effect and by the absence of soil tillage ensuring carbon storage in soil. Our findings indicated that even in no-tillage systems, thanks to the presence of a perennial crop as giant reed, low $\mathrm{N}$ input management is not able to provide an adequate litter input to the soil and keep constant SOC levels.

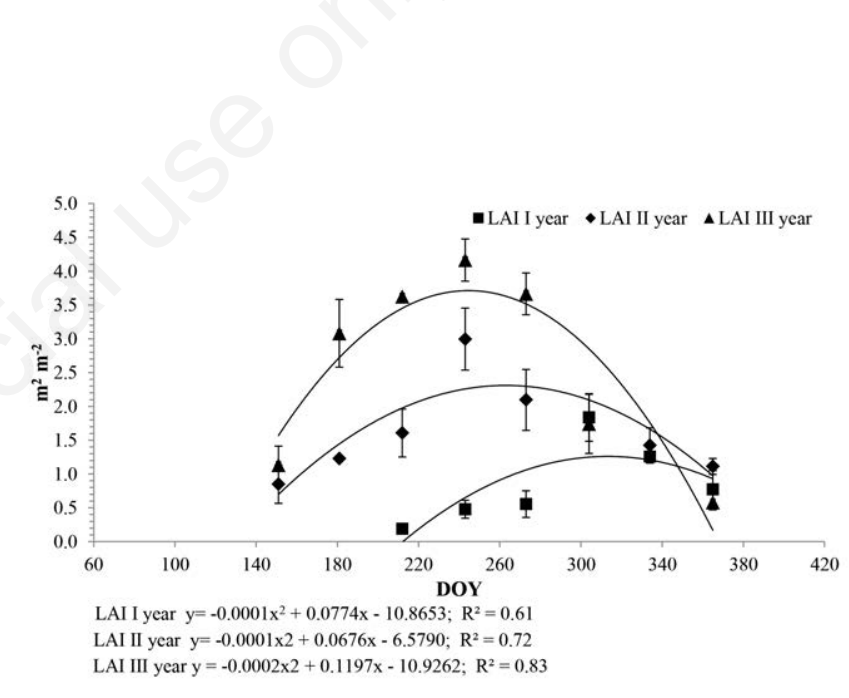

Figure 2. Changes of leaf area index $\left(\mathrm{m}^{2} \mathrm{~m}^{-2}\right)$ values (LAI) during the three year experiment (2014-2016). DOY, day of the year.

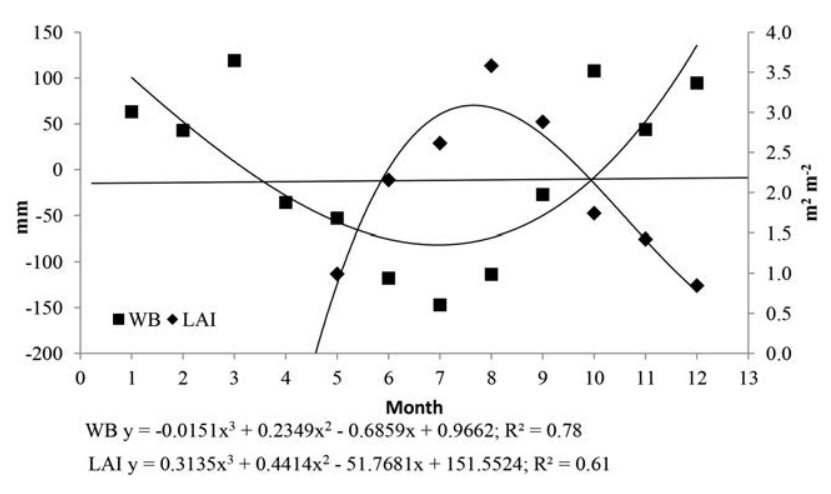

Figure 3. Monthly changes of leaf area index (LAI) and water balance (WB) average values of the years 2015 and 2016. 


\section{Soil loss reduction by giant reed cultivation}

Giant reed significantly reduced total runoff, eroded soil and sediment concentration respectively by $65 \%\left(63 \mathrm{~m}^{3} \mathrm{ha}^{-1}\right.$ vs $181 \mathrm{~m}^{3}$ $\left.\mathrm{ha}^{-1}\right), 78 \%$ (0.05 $\mathrm{Mg} \mathrm{ha}^{-1}$ vs $\left.0.21 \mathrm{Mg} \mathrm{ha}^{-1}\right)$ and $34 \%\left(0.71 \mathrm{~g} \mathrm{~L}^{-1}\right.$ vs $\left.1.08 \mathrm{~g} \mathrm{~L}^{-1}\right)$ as compared to fallow. The year by soil cover interaction showed a significant reduction of total runoff and eroded soil by giant reed cultivation as compared to fallow in all the year of experimentation (Tables 5 and 6) with the highest difference in 2018 ( $0.10 \mathrm{Mg} \mathrm{ha}^{-1}$ vs $0.66 \mathrm{Mg} \mathrm{ha}^{-1}$, on the average) when the highest autumn-winter water surplus occurred (Table 3 ). These results are in accordance with those from Fagnano et al. (2015) in previous years of the field trial (2004-2012) and are mainly due to the giant reed protective effect from rain erosivity and to the reduction in soil erodibility. In particular, the vegetation cover can improve the soil surface roughness and it works as a consecutive obstacle to surface runoff also increasing the infiltration rate (Lin et al., 2018). In addition, crop canopy can weaken rain kinetic energy by intercepting raindrops thus preventing their directly strike on ground surface (Ma et al., 2016). However, Fagnano et al. (2015) reported an higher average soil erosion under both fallow $\left(1.76 \mathrm{Mg} \mathrm{ha}^{-1}\right)$ and giant reed $\left(0.18 \mathrm{Mg} \mathrm{ha}^{-1}\right)$ as compared to that reported in this study probably related to higher rainfall intensity that has led to a greater runoff, sediment concentration and consequently increased soil erosion (Mohamadi and Kavian, 2015; Zhao et al., 2015).

Both giant reed and meadow significantly reduced $(\mathrm{P}<0.05)$ eroded soil as compared to fallow respectively by $78 \%(0.05 \mathrm{vs}$ $0.21 \mathrm{Mg} \mathrm{ha}^{-1}$ on average) and by $85 \%$ (0.03 vs $0.21 \mathrm{Mg} \mathrm{ha}^{-1}$ on the average) showing no differences between the two soil coverings (Figure 4B). This result is in accordance with Vacca et al. (2000) that showed erosion rates between 0.03 and $0.05 \mathrm{Mg} \mathrm{ha}^{-1}$ in runoff plots in Italy covered by permanent herbaceous plants.

The same tendency was reported for total runoff and sediment concentration, however by comparing the average total runoff and sediment concentration of giant reed with permanent meadow (Figure 4A), the former showed a significant higher sediment concentration $\left(0.7 \mathrm{~g} \mathrm{~L}^{-1}\right.$ vs $\left.0.5 \mathrm{~g} \mathrm{~L}^{-1}\right)$. This behaviour was in accordance with Zhao et al. (2019) and was associated to the reduced rain splash soil erosion due to the more intensive interception layer of the meadow as compared to giant reed.

According to these results, giant reed may improve ecosystem services of hilly cropping systems (Zucaro et al., 2016) subjected to water erosion. In particular, giant reed can ensure soil covering during the period (i.e., September-November) characterized by higher rain erosivity in Mediterranean conditions (Diodato et al., 2009, 2011) and reduce soil erodibility by increasing soil organic matter (Fagnano et al., 2015).

Table 5. Soil organic C (SOC) $\left(\mathrm{g} \mathrm{kg}^{-1}\right)$ at the beginning (T0) and at the end (T1) of the field trial. N50 and N100 are the two fertilization doses $\left(50\right.$ and $\left.100 \mathrm{~kg} \mathrm{~N} \mathrm{ha}^{-1}\right)$.

\begin{tabular}{lcc} 
& SOC $\left(\mathrm{g} \mathrm{kg}^{-1}\right)$ & T1 \\
N50 & T0 & 7.8 \\
N100 & 9.2 & 9.0 \\
\hline Significance & 9.0 & $*$ \\
\hline
\end{tabular}

*P $<0.05$; n.s., not significant.
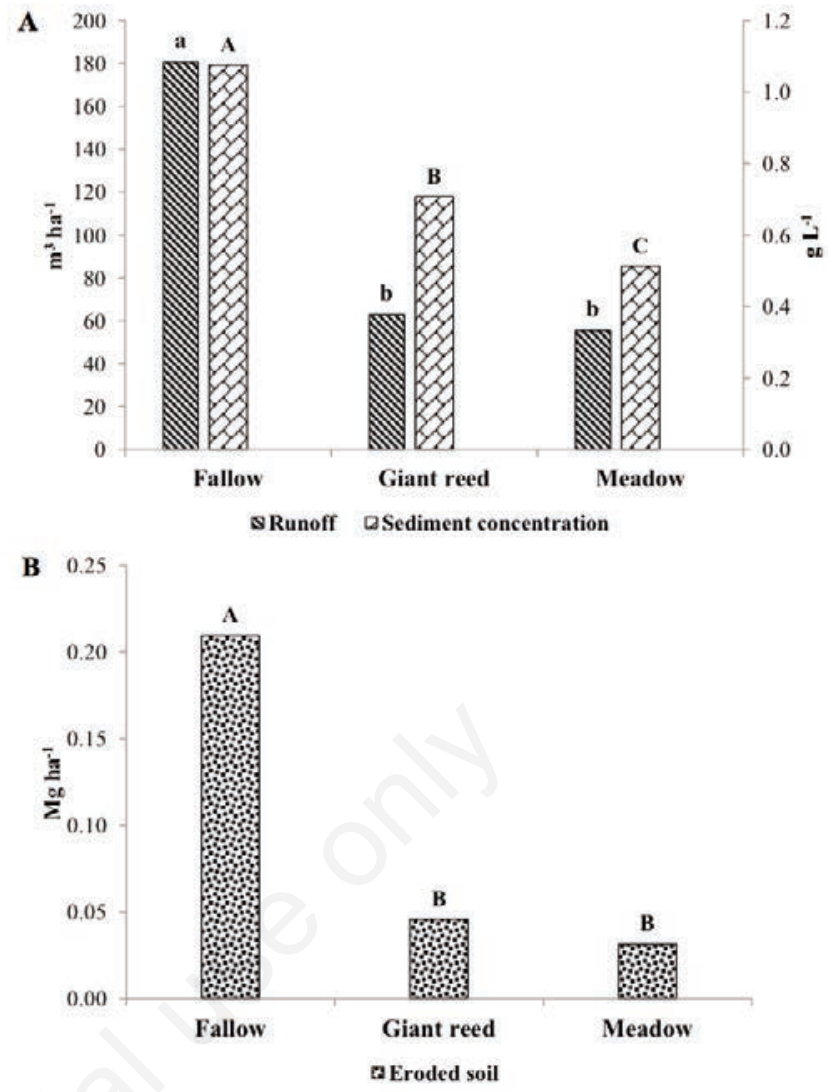

Figure 4. Total runoff $\left(\mathrm{m}^{3} \mathrm{ha}^{-1}\right)$ and sediment concentration $\left(\mathrm{g} \mathrm{L}^{-1}\right)$ (A) and eroded soil (B) under different soil cover. Bars with letters are significant according to the LSD test $(P<0.05)$. Capital letters represent differences between sediment concentration or eroded soil under different soil cover while small letters represent differences between total runoff under different soil cover. Bar graphs with the same capital or small letters are not significantly different, whereas those with different capital or small letters are significantly different.

Table 6. Total runoff $\left(\mathrm{m}^{3} \mathrm{ha}^{-1}\right)$ and eroded soil $\left(\mathrm{Mg} \mathrm{ha}^{-1}\right)$ from 2014 to 2018 with fallow and giant reed soil cover.

\begin{tabular}{llcl} 
Fallow & & $\begin{array}{c}\text { Total runoff } \\
\left(\mathrm{m}^{3} \mathrm{ha}^{-1}\right)\end{array}$ & $\begin{array}{c}\text { Eroded soil } \\
\left(\mathrm{Mg} \mathrm{ha}^{-1}\right)\end{array}$ \\
& 2014 & $258^{\mathrm{a}}$ & $0.13^{\mathrm{b}}$ \\
& 2015 & $116^{\mathrm{d}}$ & $0.10^{\mathrm{bc}}$ \\
& 2016 & $184^{\mathrm{c}}$ & $0.10^{\mathrm{cd}}$ \\
Giant reed & 2017 & $116^{\mathrm{d}}$ & $0.07^{\mathrm{de}}$ \\
& 2018 & $229^{\mathrm{b}}$ & $0.66^{\mathrm{a}}$ \\
& 2014 & $78^{\mathrm{ef}}$ & $0.04^{\mathrm{ef}}$ \\
& 2015 & $35^{\mathrm{g}}$ & $0.03^{\mathrm{f}}$ \\
& 2016 & $66^{\mathrm{ef}}$ & $0.03^{\mathrm{f}}$ \\
ANOVA & 2018 & $53^{\mathrm{fg}}$ & $0.03^{\mathrm{f}}$ \\
& Year & $82^{\mathrm{e}}$ & $0.10^{\mathrm{bc}}$ \\
& Soil cover & $* *$ & $* *$ \\
& Y $\times$ S & $* *$ & $* *$ \\
\hline
\end{tabular}

a-g Values followed by the same letter do not differ significantly according to the $\mathrm{LSD}$ test $(\mathrm{P}<0.05) .{ }^{* *} \mathrm{P}<0.01$ 


\section{Conclusions}

This work clearly demonstrates that giant reed cultivation can significantly improve ecosystem services of hilly cropping systems by reducing soil losses (up to 78\%) as compared to fallow, with a soil protection effect comparable to a permanent meadow. This effect is due to a good soil covering of giant reed (LAI values higher than 1.5) for many years during the critical months characterized by higher rain erosivity in the Mediterranean environment. An interesting biomass production was obtained adopting the higher $\mathrm{N}$ input fertilization $\left(100 \mathrm{~kg} \mathrm{~N} \mathrm{ha}^{-1}\right)$, that allowed to keep SOC constant during our trial. This means that, even if a reduction of $\mathrm{N}$ inputs is one of the main pillars in sustainable cropping systems, a low $\mathrm{N}$ input management cannot be considered as a sustainable fertilization strategy for giant reed in low fertile marginal soils being associated to both lower yields and a significant decrease of soil fertility (reduction of SOC content). The biomass production along the fifteen years of experimentation showed a decreasing trend only from the last year. However, the results indicate that even if a lower giant reed biomass yield occur in low fertile and eroded soils as compared to more fertile environments, productive levels and soil cover can be kept constant (up to 10 years after the initial 4year crop establishment phase) in comparison with more fertile environments also resulting in a longstanding soil protection from soil erosion and SOC conservation.

\section{Highlights}

- Soil erosion is an important environmental problem in Mediterranean hilly areas.

- Arundo donax L. can significantly reduce soil erosion in hilly cropland.

- Soil protection of giant reed is high during the months with higher rain erosivity.

- High $\mathrm{N}$ inputs enhance giant reed biomass production and soil fertility conservation.

- In hilly areas yields are lower but more stable over time than in more fertile environments.

\section{References}

Angelini LG, Ceccarini L, Bonari E, 2005. Biomass yield and energy balance of giant reed (Arundo donax L.) cropped in central Italy as related to different management practices. Eur. J. Agron. 22:375-89.

Angelini LG, Ceccarini L, Nassi o Di Nasso N, Bonari E, 2009. Comparison of Arundo donax L. and Miscanthus x giganteus in a long-term field experiment in Central Italy: Analysis of productive characteristics and energy balance. Biomass Bioenerg. 33:635-43.

Bonfante A, Impagliazzo A, Fiorentino N, Langella G, Mori M, Fagnano M, 2017. Supporting local farming communities and crop production resilience to climate change through giant reed (Arundo donax L.) cultivation: An Italian case study. Sci. Total Environ. 601-602:603-13.

Calvo MV, Colombo B, Corno L, Eisele G, Cosentino C, Papa G, Scaglia B, Pilu R, Simmons B, Adani F, 2018. Bioconversion of Giant Cane for Integrated Production of Biohydrogen, Carboxylic Acids, and Polyhydroxyalkanoates (PHAs) in a Multistage Biorefinery Approach. ACS Sustainable Chem.
Eng. 6:15361-73.

Cerdan O, Govers G, Le Bissonnais Y, Van Oost K, Poesen J, Saby N, Gobin A, Vacca A, Quinton J, Auerswald K, Klik A, Kwaad FJPM, Raclot D, Ionita I, Rejman J, Rousseva S, Muxart T, Roxo MJ, Dostal T, 2010. Rates and spatial variations of soil erosion in Europe: a study based on erosion plot data. Geomorphology 122:167-77.

Corno L, Lonati S, Riva C, Pilu R, Adani F, 2016. Giant cane (Arundo donax L.) can substitute traditional energy crops in producing energy by anaerobic digestion, reducing surface area and costs: a full-scale approach. Bioresour. Technol. 218:826-32.

Cosentino SL, Copani V, Scalici G, Scordia D, 2015. Soil erosion mitigation by perennial species under mediterranean environment. Bioenerg. Res. 8:1538-47.

Di Mola I, Guida G, Mistretta C, Giorio P, Albrizio R, Visconti D, Fagnano M, Mori M, 2018. Agronomic and physiological response of giant reed (Arundo donax L.) to soil salinity. Ital. J. Agron. 13:995.

Diodato N, Fagnano M, Alberico I, 2009. CliFEM - Climate forcing and erosion response modelling at long-term Sele river research basin (Southern Italy). Nat. Hazard Earth Sys. 9:1693-702.

Diodato N, Fagnano M, Alberico I, 2011. Geospatial- and visualmodeling for exploring sediment source areas across the Sele river landscape, Italy. Ital. J. Agron. 6:85-92.

Dragoni F, Ragaglini G, Calvoorneli E, Nassi o di Nasso N, Tozzini C, Cattani S, Bonari E, 2015. Giant reed (Arundo donax L.) for biogas production: land use saving and nitrogen utilisation efficiency compared with arable crops. Ital. J. Agron. 10:192-201.

Durán ZVH, Francia Martínez JR, García-Tejero I, Cuadros Tavira $\mathrm{S}, 2013$. Implications of land-cover types for soil erosion on semiarid mountain slopes: towards sustainable land use in problematic landscapes. Acta Ecol. Sinica 33:272-81.

Durán ZVH, Rodriguez PCR, 2008. Soil-erosion and runoff prevention by plant covers: a review. Agron. Sustain. Dev. 28:6586.

Fagnano M, Impagliazzo A, Mori M, Fiorentino N, 2015. Agronomic and environmental impacts of giant reed (Arundo donax L.): results from a long-term field experiment in hilly areas subject to soil erosion. Bioenerg. Res. 8:415-22.

Fernando AL, 2013. Miscanthus for a sustainable development: how much carbon is captured in the soil? pp 1842-1843 in Proc. 21st European Biomass Conference and Exhibition, Copenhagen, Denmark.

Fernando AL, Duarte MP, Almeida J, Boleo S, Di Virgilio N, Mendes B, 2010. The influence of crop management in the environmental impact of energy crops production. pp 22752279 in Proc. 18th European Biomass Conference and Exhibition, Lyon, France.

Fierro A, Forte A, Zucaro A, Micera R, Giampietro M, 2019. Multi-scale integrated assessment of second generation bioethanol for transport sector in the Campania Region. J. Clean. Prod. 217:409-22.

Forte A, Zucaro A, Faugno S, Basosi R, Fierro A, 2018. Carbon footprint and fossil energy consumption of bio-ethanol fuel production from Arundo donax L. crops on marginal lands of Southern Italy. Energy 150:222-35.

García-Ruiz JM, Nadal-Romero E, Lana-Renault N, Beguería S, 2013. Erosion in Mediterranean landscapes: Changes and future challenges. Geomorphology 198:20-36.

Guerra CA, Maes J, Geijzendorffer I, Metzger MJ, 2016. An 
assessment of soil erosion prevention by vegetation in Mediterranean Europe: Current trends of ecosystem service provision. Ecol. Indic. 60:213-22.

Hargreaves GL, Hargreaves GH, Riley JP, 1985. Agricultural benefits for Senegal river basin. J. Irrig. Drain Eng. 111:113-24.

Impagliazzo A, Mori M, Fiorentino N, Di Mola I, Ottaiano L, De Gianni D, Nocerino S, Fagnano M, 2017. Crop growth analysis and yield of a lignocellulosic biomass crop (Arundo donax L.) in three marginal areas of Campania region. Ital. J. Agron. 12:1-7.

Jien S, Wang C, 2013. Effects of biochar on soil properties and erosion potential in a highly weathered soil. Catena 110:225-33.

Klima K, Wiśniowska-Kielian B, 2006. Anti-erosion effectiveness of selected crops and the relation to leaf area index (LAI). Plant Soil Environ. 52:35-40.

Klima K, Wiśniowska-Kielian B, Lepiarczyk A, 2016. The interdependence between the leaf area index value and soil-protecting effectiveness of selected plants. Plant Soil Environ. 62:151-6.

Lin J, Zhu G, Wei J, Jiang F, Wang MK, Huang Y, 2018. Mulching effects on erosion from steep slopes and sediment particle size distributions of gully colluvial deposits. Catena 160:57-67.

Ma B, Li C, Li Z, Wu F, 2016. Effects of crops on runoff and soil loss on sloping farmland under simulated rainfall. Clean-Soil Air Water 44:849-57.

Mohamadi MA, Kavian A, 2015. Effects of rainfall patterns on runoff and soil erosion in field plots. Int. Soil Water Conserv. Res. 3:273-81.

Montagnoli A, Terzaghi M, Magatti G, Scippa GS, Chiatante D, 2016. Conversion from coppice to high stand increase soil erosion in steep forestland of European beech. Reforesta 2:60-75.

Mori M, Di Mola I, 2012. Guida alla concimazione: metodi, procedure e strumenti per un servizio di consulenza. Imago Editrice s.r.l., Rimini, Italy.

Nassi o Di Nasso N, Angelini LG, Bonari E, 2009. Improving energy crop cultivation in the Mediterranean region: nutrient content, uptake and nutrient use efficiency in giant reed (Arundo donax L.). pp 321-322 in Proc. 16th Nitrogen WorkshopConnecting Different Scales of Nitrogen Use in Agriculture, Turin, Italy.

Nassi o Di Nasso N, Angelini LG, Bonari E, 2010. Influence of fertilisation and harvest time on fuel quality of giant reed (Arundo donax L.) in central Italy. Eur. J. Agron. 32:219-27.

Ola A, Dodd IC, Quinton JN, 2015. Can we manipulate root system architecture to control soil erosion? Soil 1:603-12.

Pena SB, Abreu MM, Magalhães MR, Cortez N, 2020. Water erosion aspects of land degradation neutrality to landscape planning tools at national scale. Geoderma 363:114093.
Pulighe G, Bonati G, Colangeli M, Morese MM, Traverso L, Lupia F, Khawaja C, Janssen R, Fava F, 2019. Ongoing and emerging issues for sustainable bioenergy production on marginal lands in the Mediterranean regions. Renew. Sustain. Energy Rev. 103:58-70

Ricci GF, Jeong J, De Girolamo AM, Gentile F, 2020. Effectiveness and feasibility of different management practices to reduce soil erosion in an agricultural watershed. Land Use Policy 90:104306.

Rickson RJ, 2014. Can control of soil erosion mitigate water pollution by sediments? Sci. Total Environ. 468-69:1187-97.

Song Z, Seitz S, Zhu P, Goebes P, Shi X, Xu S, Wang M, Schmidt $\mathrm{K}$, Scholten T, 2018. Spatial distribution of LAI and its relationship with throughfall kinetic energy of common tree species in a Chinese subtropical forest plantation. Forest Ecol. Manag. 425:189-95.

Vacca A, Loddo S, Ollesch G, Puddu R, Serra G, Tomasi D, Aru A, 2000. Measurement of runoff and soil erosion in three areas under different land use in Sardinia (Italy). Catena 40:69-92.

Vanmaercke M, Poesen J, Verstraeten G, De Vewnte J, Ocakoglu F, 2011. Sediment yield in Europe: spatial patterns and scale dependency. Geomorphology 130:142-61.

Walkley A, Black IA, 1934. An examination of Degtjareff method for determining soil organic matter and a proposed modification of the chromic acid titration method. Soil Sci. 37:29-37.

Wang L, Zhang F, Fu S, Shi X, Chen Y, Jagirani MD, Zeng C, 2020. Assessment of soil erosion risk and its response to climate change in the mid-Yarlung Tsangpo River region. Environ. Sci. Pollut. Res. 27:607-21.

Webster R, 2005. Morgan, R.P.C. Soil Erosion and Conservation, 3rd edn. Blackwell Publishing, Oxford, UK.

Zhang Y, Liu B, Zhang Q, Xie Y, 2003. Effect of different vegetation types on soil erosion by water. Acta Bot. Sin. 45:1204-9.

Zhang W, Yu D, Shi X, Wang H, Gu Z, Zhang X, Tan M, 2011. The suitability of using leaf area index to quantify soil loss under vegetation cover. J. Mt. Sci. 8:564-70.

Zhao Q, Li D, Zhuo M, Guo T, Liao Y, Xie Z, 2015. Effects of rainfall intensity and slope gradient on erosion characteristics of the red soil slope. Stoch. Env. Res. Risk A. 29:609-21.

Zhao B, Zhang L, Xia Z, Xu W, Xia L, Liang Y, Xia D, 2019. Effects of rainfall intensity and vegetation cover on erosion characteristics of a soil containing rock fragments slope. Adv. Civil Engine. 2019:7043428.

Zucaro A, Forte A, Basosi R, Fagnano M, Fierro A, 2016. Life cycle assessment of second generation bioethanol produced from low-input dedicated crops of Arundo donax L. Bioresour. Technol. 219:589-99. 